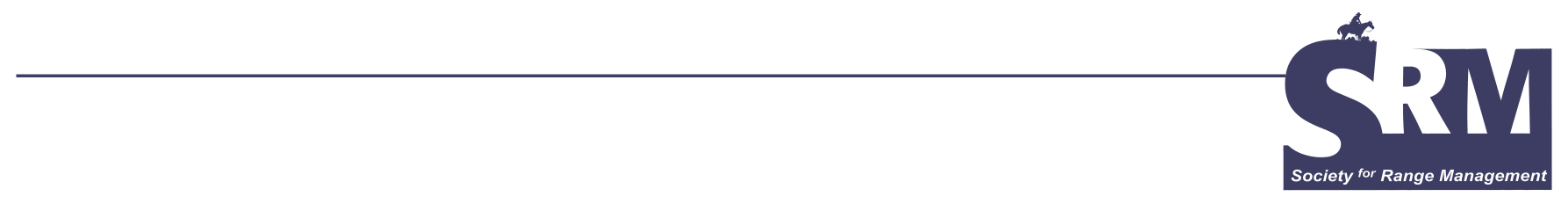

\title{
Rangeland Water Matters to Everyone!
}

\section{By Mike Mecke}

$\mathrm{I}$ am going to pose some questions about your water source for your thought and actions. Our Earth is known as the Blue Planet because of the blue color we see from space, caused by the large amounts of water present on its surface. But most of the earth's water is undrinkable, salty ocean water or sometimes brackish groundwater. At least undrinkable without facing often high costs for treatment, disposal of the toxic salt waste products, and cost of transporting.

A website known as the Water Page states it this way.

If a large bucket of water were to represent the sea water on the planet, an egg cup full would represent the amount of water locked in ice caps and glaciers and a teaspoonful would be all that was available as drinking water.

Years ago, due to a family emergency, I left the Bureau of Indian Affairs in Wyoming and moved home to San Antonio to enter the water-resources profession. As all good range folks are trained to think and act, as watershed managers, I was selected to work in water-resources planning and later in $\mathrm{Ag}$ conservation. The lone $\mathrm{Ag}$ graduate in a department of urban planners and engineers! But, we learned a lot from each other I believe. I had long been concerned with water, watersheds, and soil conservation from my Texas $\mathrm{A} \& \mathrm{M}$ classes and into my early Range Conservationist years with the former Soil Conservation Service.

Many decades ago, a profound statement by Dr Thad Box, former Dean at Utah State University, made a lasting impression on me. In a JRM article, Dr Box said something like "someday, the most important product from rangelands will be pure water!" That has always stuck with me and I am

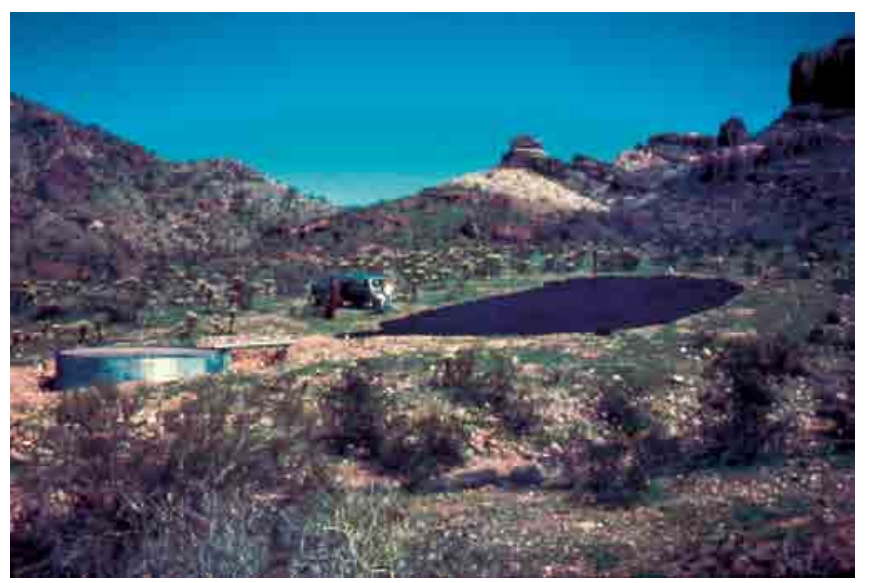

Water-harvesting facility for wildlife drinking water in western Arizona. Photo courtesy of Gary Frasier.

a firm believer in the wisdom of that statement. Rangelands do make up a high majority of the watersheds in the western half of the United States, which is the area I am mostly writing of today. The truth of the statement is now more apparent than ever. It has become a proven fact even to many nonrange people.

Our use of freshwater resources such as rivers and lakes has steadily increased over the centuries. Human population has exploded across much of the world and many of our nations now use many times the amount of water actually needed for life. Quite often, we have too many people living and working in dry areas that cannot support them in a sustainable manner. Many of our large, growing cities across the Sunbelt are now experiencing water shortages or have projected shortages in coming decades. 


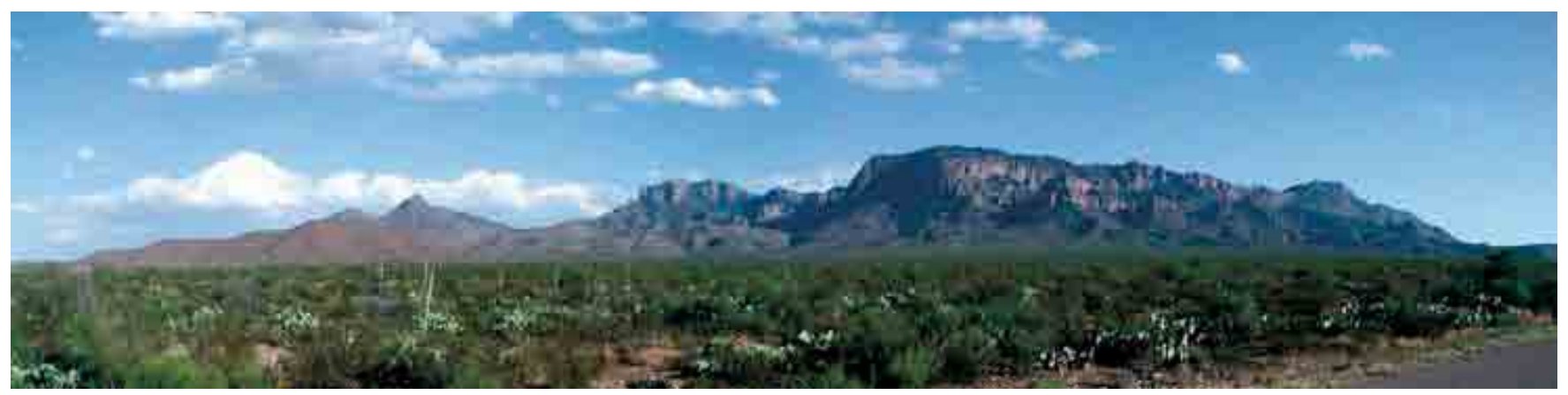

Chisos Mountains, courtesy Big Bend National Park.

In Texas and elsewhere in the West, we range conservationists are very familiar with the ranching term "carrying capacity." This refers to keeping your forage (and water) supplies on a ranch in balance with the livestock herd, including the wildlife populations present. Well, I believe that our world has human carrying capacities also, especially water supplies. Are we always in balance with our carrying capacity in the arid and semiarid areas of the American Southwest and West? Or even some Southeastern areas? Florida has huge water problems. Are we leaving enough clean water in our creeks, rivers, aquifers, wetlands, and bays to keep them healthy and functional? Or, have we paved, channeled, developed, drained, or otherwise improved those water bodies and their watersheds? Do we treat all lands as a watershed? All lands are watersheds, as you know. I don't believe in many cases we are. We often get by in taking from Peter to pay Paul. Or have we left the problems for the next generation to fix?

With rapid population growth and increasing domestic, industry, and recreational water use, water is becoming an incredibly valuable resource but is still largely undervalued at our water meters and irrigation district offices. Price usually influences people's perceptions of an object's value. Many water experts feel that much of our extra water needs will come from irrigated agriculture in the future. Certainly, in many cases, irrigation can be done much more efficiently than it is now. Or does this mean that we will return these profitable, valuable irrigated fields to less productive native grasslands or desert? I have seen many hundreds of formerly irrigated fields in Arizona, New Mexico, and Texas abandoned to become weed-infested dust bowls causing other problems. Will we someday fairly soon buy much of the food and fiber needs of our states and nation from other countries? Becoming a Third World country in agriculture? What happens to the families, communities, and regions depending on irrigated agriculture's income and jobs? Or of the ranches depending on irrigated pastures for winter or summer forage? There could be a ripple effect economically that can reach far away, maybe even into the cities purchasing this water.

This rapid population growth and increased human water use has caused an explosion of water marketing/selling, trading, and leasing. Sound familiar? It does in Texas or in the Colorado River basin. These have become target areas, both for selling and buying of water and water rights, as have regions in other states. In Texas, we now have regular seminars on water marketing, something unheard of 10 years ago. Not only are US entrepreneurs involved, but foreign-owned water companies are also now investing in ownership and operation of water rights and utilities across the nation. Do Americans want and need that? Or should we own and manage our own water resources?

It is not only the scarcity of water that is becoming an issue, but also water quality. We know that properly managed rangelands, riparian areas, and wetlands not only produce water for our needs, but purify that water too. Auto/jet fuels, mineral fertilizers, home and agricultural pesticides, pathogens, and industrial by-products have seeped into aquifers and surface waters, contaminating them beyond human consumption and disrupting delicate ecosystems. We are now seeing some of our rivers polluted with pharmaceutical products that may affect not only those ecosystems but human water users downstream. Who would have ever dreamed that? Our towns and cities have sometimes indiscriminately dumped sewage, industrial wastes, and toxic pollutants into rivers and lakes, threatening the world's most important resource, fresh water. Ultimately, our bays and oceans are paying the price for our carelessness and negligence in protecting water resources.

Some US rivers and bays have become unfit for swimming or fishing, let alone for livestock or our own drinking. Unfortunately, Texas is in that group of states with many water-quality concerns. We need look no further than our beloved and historic Rio Grande/Rio Bravo or Pecos Rivers for examples. The ongoing 7-10-year drought across New Mexico, western Texas, and eastern Mexico has only made the current situation worse. This drought has spread north to Montana and west to the Pacific, further stressing our rangeland watersheds and riparian systems. Even Las Vegas is now conserving water. What next?

Will there be enough drinkable water to accommodate the needs of future generations of Americans and others worldwide? Will irrigated agriculture survive and prosper? Will it be affordable to all? There will be, if we properly 
manage all of our watersheds, water supplies, and plan our growth with this irreplaceable resource at the top of our lists. A planning method termed Smart Growth is not just a method of saving agricultural lands, reducing congestion, improving air quality, and saving wildlife habitat. Smart Growth can also be a method of properly planning waterresources development and management.

Water availability is the question that many of us in the water arena now wrestle with and try to address daily. It is also the issue that our children and grandchildren will face due to exploding human populations and the same amount of water. So, do your share NOW to conserve water and to keep our water supplies pure! Lead by example. Be a goodno, a great-steward of your land, whether 100 sections of rangeland or a home lot or a business site. Properly manage those watersheds and riparian areas so that they not only produce the forage and wildlife habitat needed but produce the clean water that we all require.

Conservation must always be No. 1 on our water resources planning list, as the water we save is always our cheapest water! Did you know that most home landscapes use from $40 \%$ to $60 \%$ of the family's total water use? We are doing better in urban conservation, especially in Tucson, San Antonio, E1 Paso, Albuquerque, and some other cities, but we are far from doing our best. We Americans love to be

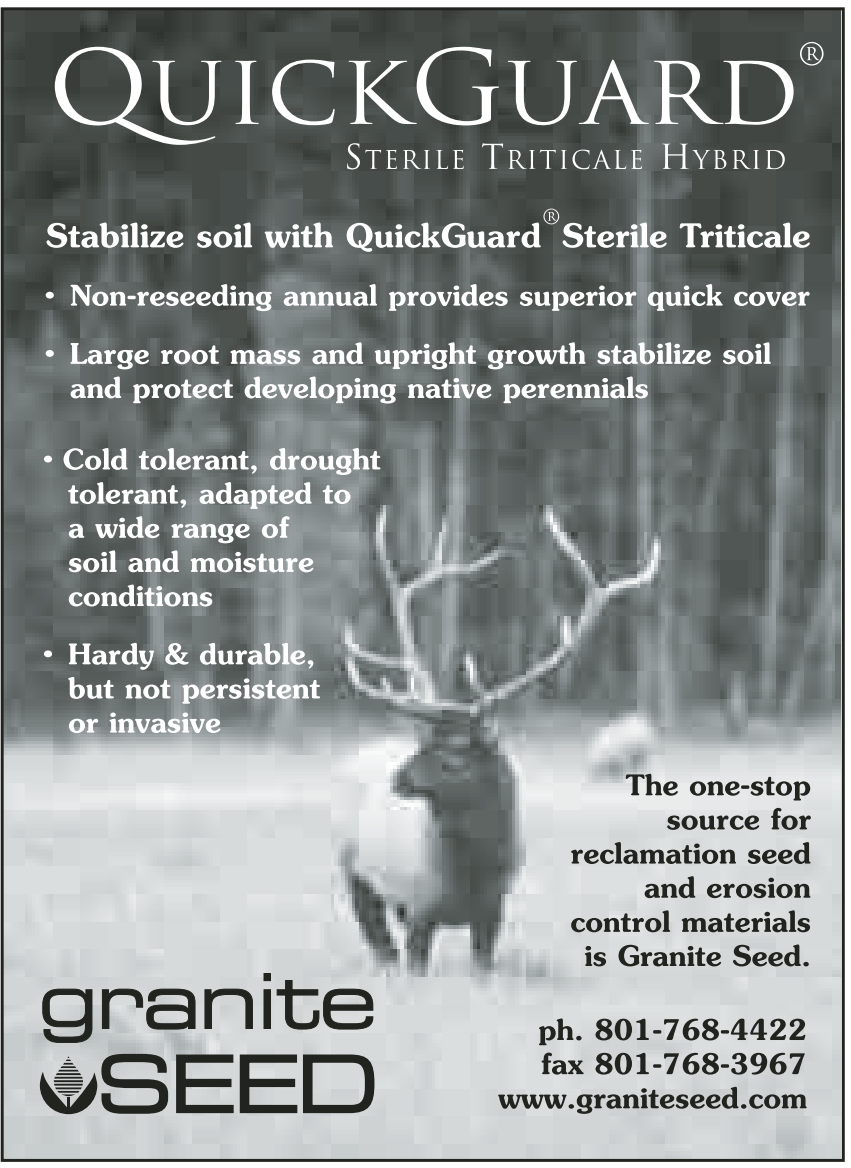

No. 1; it's in our genes; so why not try to be No. 1 in lowest water use per person? This should also be done in our farm and ranch homes. That achievement will do wonders for our water resources and for the future of our economy. When I was a Range Section Chief on the Papago Reservation in southern Arizona, I saw entire herds watered on rainwater catchments and then saw this again in Wyoming. Also, high evaporation rates of tank water had led to experimental floating covers. This is becoming a growth business now in arid west Texas. Your rangelands can do the same!

If we do our best at achieving sustainable rangelands and water resources, then the future will be brighter. Working closely with our neighbors in Mexico and Canada is part of the answer that we range and water professionals must address. We share not only water but watersheds. We must aim for sustainability, but achieving it will take all of us working together.

Water is not a commodity like oil. There are many substitutes for oil. But for water, none! Truly, water is life-or, as we say in the Southwest, agua es vida!

Mike Mecke is Water Resources Specialist, Texas Cooperative Extension, Texas Water Resources Institute, PO Box 1298, Fort Stockton, TX 79735.

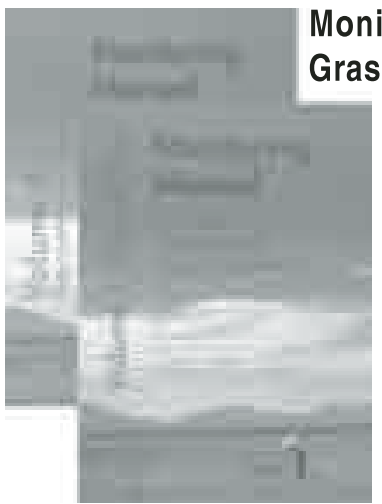

Monitoring Manual for Grassland, Shrubland, and Savanna Ecosystems Jeffrey E. Herrick, Justin W. Van Zee, Kris M. Havstad, Laura M. Burkett, and Walter G. Whitford This book describes the first integrated soil and vegetation monitoring system for rangeland ecosystems and is also the only monitoring guide to address the increasingly popular concept of "rangeland health." Rather than focusing on any particular land management objective such as livestock production, watershed protection, or biodiversity conservation, the manual describes how to monitor basic ecosystem attributes on which all land uses depend: soil and site stability, watershed function, and biotic integrity

Distributed for the Jornada Experimental Range, USDA

Two volumes ( $\left.8 \frac{1}{2} \times 11\right), 36+200$ pp., 130 illus., \$24.95s paper

\section{Sonoita Plain}

Views from a Southwestern Grassland Text by Carl E. Bock and Jane H. Bock Photographs by Stephen E. Strom Foreword by Patricia Nelson Limerick 144 pp. , 34 color plates, 22 illus., \$20.00 paper

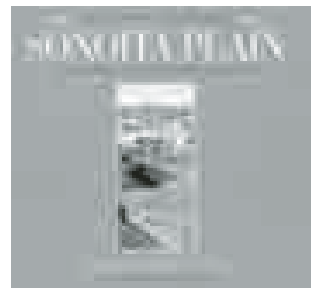

The University of Arizona Press Tucson, AZ 85712 • 1-800-426-3797 www.uapress.arizona.edu 